The University of Maine

\title{
DigitalCommons@UMaine
}

Earth Science Faculty Scholarship

Earth Sciences

$12-1983$

\section{Nitrate Plus Nitrite Concentrations in a Himalayan Ice Core}

William Berry Lyons

Paul Andrew Mayewski

University of Maine, paul.mayewski@maine.edu

Follow this and additional works at: https://digitalcommons.library.umaine.edu/ers_facpub

Part of the Environmental Sciences Commons, Glaciology Commons, Hydrology Commons, and the Meteorology Commons

\section{Repository Citation}

Lyons, William Berry and Mayewski, Paul Andrew, "Nitrate Plus Nitrite Concentrations in a Himalayan Ice Core" (1983). Earth Science Faculty Scholarship. 188.

https://digitalcommons.library.umaine.edu/ers_facpub/188 


\title{
NITRATE PLUS NITRITE CONCENTRATIONS IN A HIMALAYAN ICE CORE
}

\author{
Wm. Berry Lyons and Paul A. Mayewski
}

Department of Earth Sciences and Ocean Process Analysis Laboratory, University of New Hampshire, Durham, NH 03824

\section{Introduction}

The measurement of chemical constituents in glacial ice has been useful in discerning historic trends in chemical deposition and hence paleo-atmospheric records in remote areas (Thompson and Mosley - Thompson, 1981; Johnson and Chamberlain, 1981; $\mathrm{Ng}$ and Patterson, 1981; Neftel et al., 1982). However, delineating the sources of the deposited chemical species in question is not always straightforward. This has been especially true for nitrate. Although it is now believed that man-made emissions are responsible for a high percentage of nitrate being deposited in remote areas of the Northern Hemisphere, numerous natural sources, named and unnamed, have also contributed to the precipitated nitrate burden in these regions (Risbo et al., 1981; Herron, 1982). Most of the data available for glacial ice has been obtained from polar glaciers. We present nitrate plus nitrite data from a $16.6 \mathrm{~m}$ core collected at $4908 \mathrm{~m}$ on Sentik Glacier in the Nun Kun portion of the Ladakh Himalayas, India. To our knowledge this is the longest record of nitrate concentrations reported from an alpine glacier.

\section{Sampling Area}

Nun Kun $\left(75^{\circ} 71^{\prime}\right.$ to $76^{\circ} 08^{\prime} \mathrm{E}$ long., $34^{\circ} 57^{\prime}$ to $35^{\circ} 02^{\prime} \mathrm{N}$ lat.,) is commonly used as the name for the rectangular massif $(25 \times 13 \mathrm{~km})$ at the northwestern end of the Zanskar Range, Ladakh. It was chosen as a site from which to retrieve a paleoatmospheric record because in addition to containing several glaciers that radiate off its central snow-covered plateau, it is a relatively arid portion of the Himalayas, close to the northern limit of the summer monsoon. Therefore, it is potentially an area sensitive to monsoonal fluctuations. A more detailed description of the sampling location is presented in Mayewski et al. (in press)

\section{Sampling and Analytical Procedures}

A total of 103 samples were recovered from the core for nitrate plus nitrite analysis using a Teflon coated SIPRE auger. Upon retrieval of the samples in the field, they were handled with polyethylene gloves, sectioned and to alleviate contamination by the coring procedure, scraped with precleaned plexiglass cutters which were stored wrapped in plastic prior to use. Samples were placed into precleaned polyethylene bags, sealed and allowed to melt. Within $24 \mathrm{hr}$ the melted ice was transferred to $125 \mathrm{ml}$ linear polyethylene (LPE) bottles, the bottles placed into polyethylene bags, the bags sealed and stored in the dark until shipment back to Durham, New Hampshire.

The polyethylene bags and bottles used for sample collection and storage were washed in soap and water and rinsed several times with distilled-deionized water. This mode of cleaning was chosen as opposed to acid cleaning because our laboratory studies indicate that the cleaning of LPE bottles with concentrated $\mathrm{HCl}$ results in high nitrate plus nitrite blanks even after five rinses with distilled-deionized water (Table 1). The polyethylene bags gave much lower blanks than the bottles but it was felt that any acid treatment of either bags or bottles was unacceptable. Soap and water washed and distilled-deionized rinsed bottles and bags

Copyright 1983 by the American Geophysical Union.

Paper number 3L1030.

$0094-8276 / 83 / 003 \mathrm{~L}-1030 \$ 03.00$ showed little sign of nitrate plus nitrite contamination so this technique was chosen for our study. The melted samples were stored in the dark and analyzed for nitrate plus nitrite colorimetrically via cadmium reduction using a Technicon Auto Analyzer ${ }^{\mathrm{T} M}$ system within four months of collection. Analytical precision determined from replicate analyses of $2.00 \mu \mathrm{M}$ standards reported as a coefficient of variation was $1.5 \%$. Recently Herron (1982) has suggested that the analysis of $\mathrm{NO}_{3}{ }^{-}$in snow and ice using cadmium-reduction techniques may yield erroneously high results. Based on the results obtained by us from a number of different alpine environments (see below) we feel that this suggestion may be premature. In addition, Risbo et al. (1981) have utilized the cadmium reduction technique on Greenland ice samples obtaining similar results as Herron (1982). Only through detailed intercalibration studies of glacier ice using both cadmium reduction colorimetry and ion chromatography can this question be better resolved.

\section{Results}

The nitrate plus nitrite concentration versus depth in the Sentik Glacier core is shown in Figure 1 . The values range from 4.4 to less than $0.1 \mu \mathrm{M}$ with a mean value of $1.4 \mu \mathrm{M}$. The mean is similar to the mean value of $1.1 \mu \mathrm{M}$ reported for a short core from Athabasca Glacier, the Canadian Rockies (Butler et al., 1980). Values of nitrate in preindustrial Greenland ice appear to cluster around $0.8 \mu \mathrm{M}$ with values as high as $2.5 \mu \mathrm{M}$ reported (Herron, 1982). Stallard and Edmond (1981) have reported a value of $3.4 \mu \mathrm{M}$ for few day old surface snow from the Brazilian Andes. These data are summarized in Table 2. The values reported by us are therefore similar to those reported for ice and snow in other remote areas.

Using the example of Zeller and Parker (1981), we have attempted to summarize all the plausible causes of nitrate concentration in remote precipitation. The origin and the variation of nitrate plus nitrite down the core in our study could be caused by the following mechanisms: 1) nitrogen fixation via lightning; 2) preferential melt out and recrystallization; 3) variation in air mass source of the precipitation and/or 4) variation in anthropogenic input; 5) variation in solar related phenomenon; 6) variation in local and/or regional biological input; 7) variation in volcanic input; 8) variation in snow accumulation rate; 9) variation in dry vs. wet deposition and/or 10) variation in some other unknown factor.

Complete evaluation of these hypothetical sources leading to the variations of nitrate plus nitrite concentrations is impossible at this time, however based on the information available we can eliminate some and promote others. Although nitrogen fixation via lightning cannot be tested directly it is unlikely that this mechanism is responsible for the majority of the nitrate plus nitrite in the snow or their variation with depth. This area of India appears to be one of relatively low lightning frequency (Turman, 1979).

Davies et al. (1982) have shown that strong mineral acids including $\mathrm{HNO}_{3}$ preferentially leached from glacial "melt out" events at warmer times of the year result in the production of down hole profiles that do not resemble the original composition of the snow at the time of deposition. Several lines of evidence suggest that this has not happened to any great extent at our Sentik sampling site. First, the $-3^{\circ} \mathrm{C}$ mean annual temperature determined at our sampling location, extrapolation of radiosonde measurements to the study area, 
TABLE $1 . \mathrm{NO}_{3}^{-}+\mathrm{NO}_{2}^{-}$Values in $\mu \mathrm{M}$ (from distilleddeionized water which had been stored in acid washed and soap and water washed LPE bottles).

$\frac{\text { Acid washed }}{5.3 \pm 1.3} \quad \frac{\begin{array}{c}\text { Soap and } \\ \text { water washed }\end{array}}{\leq 0.1}$

monitoring of melting at the site and covariation of various soluble and nonsoluble chemical species profiles down hole (Mayewski et al., in press) all indicate little to no melting at this site. In addition, fresh surface snow nitrate plus nitrite values from the study area have similar values to what we have observed down hole at the Sentik site (Mayewski et al., 1983).

Variations in source of air mass to the study area as a cause of chemical variation has been investigated via collection of fresh surface snow from the Nun Kun region (Mayewski et al., 1983). These samples ranged in elevation from 5130 to $5512 \mathrm{~m}$. Chemical data including deuterium, reactive iron, chloride, reactive phosphate, $\mathrm{pH}$ and ammonium as well as nitrate plus nitrite suggest that the snow precipitated during this event originated from two distinct air masses (Mayewski et al., 1983). The higher elevation more pristine air mass contained higher concentrations of nitrate plus nitrite. Ikegami et al. (1980) have reported relatively high concentrations of sulfuric acid particles with increases in elevation in Nepalese Himalayan aerosols. By analogy Mayewski et al. (1983) proposed that the major source of aerosols to the air mass above $5300 \mathrm{~m}$ in this region are the trace gases $\mathrm{SO}_{2}$ and $\mathrm{NO}_{\mathrm{x}}$. It is therefore possible that a significant portion of the nitrate plus nitrite variation down hole in the Sentik core is due to differences in air mass over this region.

It is doubtful that the variation in nitrate plus nitrite is due to variation in anthropogenic input. Although the burning of wood and dung in localized areas can contribute various chemical species to precipitation in the Himalayas (Davidson et al., 1981a), and nitrogen oxides are produced in large quantities via wood burning (Dasch, 1982), the nitrate plus nitrite values in surface snows from the Sentik area indicate little anthropogenic input from lower elevations. In fact, as noted previously the highest nitrate plus nitrite values are associated with relatively high elevation air masses (Mayewski et al., 1983). Anthropogenic nitrate transported from long-range is probably an unlikely source. Studies in areas affected by anthropogenic aerosol input indicate that nitrate may be selectively removed during longrange transport of the aerosol (Jickells et al., 1982). This is undoubtedly due in part to the relatively short residence time of anthropogenically introduced $\mathrm{NO}_{\mathrm{x}}$ in the atmosphere (Spicer, 1982).

There has been a considerable debate in recent years regarding the importance of nitrate input in polar snows via various types of solar activities. Zeller and Parker (1981) and Parker et al. (1982) have supported this hypothesis as a major source of nitrate to Antarctic snow and ice while Risbo et al. (1981) have argued against it as a major source of nitrate to northern polar ice and Herron (1982) finds no evidence of nitrate concentrations being modulated by solar activity in samples collected in Greenland. Using the simplifying assumption that the nean net mass balance for the Sentik glacier core has been uniform over the $\sim 18 \pm 0.3 y$. record represented by the total $\beta$-activity dated core (Mayewski et al., in press) a comparison between sunspot data (after Zeller and Parker, 1981) and nitrate plus nitrite in the profile is made in Figure 1. Agreement between the two data sets appears to be good but cannot be investigated in detail due to problems in assessing absolute net balance per year and differences in sampling interval between data sets. The comparison does, however, lend support to the concept that fluctuations may be modulated by solar activity.

Recently a number of investigators have shown that naturally produced nitrogen, sulfur and phosphorus compounds are injected into the atmosphere via biological processes especially in tropical to semi-tropical rain forest environments (Lawson and Winchester, 1979; Stallard and Edmond, 1981; Haines, in press). In addition, nitrogen compounds are liberated from soils especially during warmer months (Yaalon, 1964) and this soil production may exercise a major role in the $\mathrm{NO}_{\mathrm{x}}$ budget of the troposphere especially in remote regions where anthropogenic activity is minimal (Lipschultz et al., 1981). Ladakh is a semi-arid region with a short growing season and biological input is seasonal probably contributing little to the nitrogen burden of these samples. This is further supported by the fact that the mean molar ratio of nitrate plus nitrate-N/phosphate-P in all the samples except those of abundant debris bands where the phosphate values are very high (Mayewski et al., in press) is approximately 20 . This value is approximately 2 times higher than the molar ratio of terrestrial vegetation (average of above and below ground biomass from Likens et al., 1977) suggesting that there is another major nitrate plus nitrite source to the snow and ice samples. Furthermore, time-series analysis of the downcore nitrate plus nitrite yields no recognizable power that could be attributed to annual inputs such as biological activity during the warm season (Mayewski et al., in press).

Volcanism although a potential source of nitrate is difficult to evaluate in our samples. Kyle et al. (1982) have observed volcanically input nitrate in Antarctic samples while Risbo et al. (1981) have observed no such input in Greenland samples. The Agung eruption of 1963 is clearly recorded in Antarctic and Greenland ice over the period 19641968 by its increased contribution of sulfate and acidity (Delmas and Boutron, 1978; Hammer, et al., 1980; Rampino and Self, 1982). Whether a significant contribution of nitrate was also deposited is unknown. This time period may represent the bottom $3-4 \mathrm{~m}$ of this core and, in general, the nitrate plus nitrite values are lower than in higher sections of the core. This of course does not rule out a volcanic nitrate plus nitrite contribution but it does, we feel, eliminate volcanism as a major source.

The importance of accumulations rate in the presence of anomalous concentrations at depth and/or in core interpretation in general is not well known although studies comparing Greenland and Antarctic snow accumulation rates versus sulfate and nitrate concentrations suggest that snow accumulation rates above $400-500 \mathrm{~kg} \cdot \mathrm{m}^{-2} \cdot \mathrm{y}^{-1}$ have little effect on species concentration (Herron, 1982). Although only net mass balance is known for Sentik Glacier (Mayewski et al., in press) there is little doubt that the accumulation rate for this

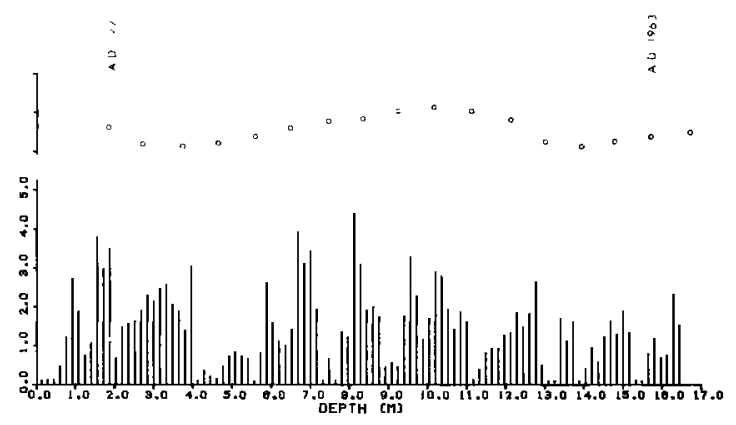

Figure 1. Downhole plot of nitrate plus nitrite (bars) compared to relative sunspot activity (circles). The latter is from Zeller and Parker (1981). $\mathrm{NO}_{3}^{-}+\mathrm{NO}_{2}^{-}$values in $\mu \mathrm{M}$. 
TABLE 2. Nitrate Concentrations in Snow and Ice From Remote Locations

\begin{tabular}{|c|c|c|}
\hline Location & Concentration & Reference \\
\hline $\begin{array}{l}\text { Athabasca Glacier } \\
\text { Alberta, Canada }\end{array}$ & $1.1 \mu \mathrm{M}^{*}$ & Butler et al. (1980) \\
\hline Greenland & $\sim 0.8 \mu \mathrm{M}$ & Herron (1982) \\
\hline Andes, Brazil & $3.4 \mu \mathrm{M}$ & $\begin{array}{l}\text { Stallard and Edmond } \\
\text { (1981) }\end{array}$ \\
\hline $\begin{array}{l}\text { Sentik Glacier, } \\
\text { Indian Himalayas }\end{array}$ & $1.4 \mu \mathrm{M}^{*}$ & This work \\
\hline
\end{tabular}

*Mean values

glacier is considerably, minimum $620 \mathrm{~kg} \cdot \mathrm{m}^{-2} \cdot \mathrm{y}^{-1}$, higher than that found in Greenland and Antarctica. It is possible, however, that the variation of nitrate plus nitrite in the Sentik core may be due to variations in snow accumulation rate with higher values occurring at times of low accumulation rates. If this is the case it seriously complicates the interpretation of nitrate concentration profiles in ice cores (Herron, 1982).

If nitrate plus nitrite is deposited via dry deposition during times of snow hiatuses, the variation of nitrate plus nitrite could be explained in this manner. Davidson et al. (1981b) have shown that dry deposition in Greenland accounts for a small percentage of the total net deposition for elements and compounds with high enrichment factors such as sulfate. To our knowledge similar comparisons have not been made in remote areas for nitrate, but recently Herron (1982) has argued that dry fallout of nitrate is minimal in Greenland.

The nitrate plus nitrite variation observed by us could also be due to some unknown factor. Both Risbo et al. (1981) and Herron (1982) have observed seasonal variation in Greenland ice and snow with higher concentrations observed in the spring-summer period. Herron (1982) has argued that the ocean is not the source of background nitrate in polar snows. Risbo et al. (1981) have suggested that the higher deposition rate of nitrate in the spring-summer is due to stratospheric fallout after the opening of the spring troposphere-stratosphere exchange. Although the time-series analysis performed on the Sentik core nitrate plus nitrite data provides no evidence of an annually repeating event, this does not exclude the possibility that every few years, during the springsummer season, nitrate plus nitrite concentrations do not rise. The cause of such a rise, however, remains speculative.

\section{Conclusions}

The nitrate plus nitrite concentrations observed in a $16.6 \mathrm{~m}$ core from $4908 \mathrm{~m}$ in the Ladakh Himalayas are similar to what has been observed in snow and ice from other remote regions. Although absolute confirmation cannot be made at this time, the variation of nitrate plus nitrite may be due to the following processes: 1) variation in air mass chemistry; 2) variation in solar related phenomenon; 3) variation in snow accumulation rate and/or 4) some other unknown factor such as seasonally occurring exchanges in the upper atmosphere.

Acknowledgments. Members of the 1980 Nun Kun Expedition included P.A. Mayewski (leader), Wm. B. Lyons, P. Axelson, P.A. Jeschke and J. Sevigny of the University of New Hampshire, N. Ahmad, M.N. Kaul and K. Kahn of Aligarh Muslim University and P.T. Davis of Mount Holyoke College. We would like to thank Ghulam Ali and the people of Tongul, Ladakh for all of their help in this project. G. Smith, University of New Hampshire kindly conducted the analyses referred to in this study and P. Jeschke and B. Allen carried out the blank studies. This study is part of a joint U.S.-Indian study of Himalayan glaciers, funded by U.S. National Science Foundation Grant INT-80-03175. A permit for this study was provided by the Government of India and their cooperation and help in this program is very much appreciated.

\section{References}

Butler, D., W.B. Lyons, J. Hassinger and P.A. Mayewski, Shallow core snow chemistry of Athabasca Glacier Alberta, Can. Jour. Earth Sci., 17, 278-281, 1980.

Dasch, J.M., Particulate and gaseous emissions from woodburning fireplaces, Environ. Sci. Tech., 16, 639-645, 1982.

Davidson, C.I., T.C. Grimm and M.A. Nasta, Airborne lead and other elements derived from local fires in the Himalayas, Science, 214, 1344-1346, 1981a.

Davidson, C.I., L. Chu, T.C. Grimm, M.A. Nasta and M.P. Qamoos, Wet and dry deposition of trace elements onto the Greenland ice sheet, Atmos. Environ., 15, 1429-1437, $1981 \mathrm{~b}$.

Davies, T.D., C.E. Vincent and P. Brimblecombe, Preferential elution of strong acids from a Norwegian ice cap, Nature, 300, 161-163, 1982

Delmas, R. and C. Boutron, Sulfate in Antarctic snow: Spatiotemporal distribution, Atmos. Environ., 12, 723-728, 1978.

Haines, B., Forest ecosystem $\mathrm{SO}_{4}-\mathrm{S}$ input-output discrepancies and acid rain: are they related? Oikos, in press.

Hammer, C.U., H.B. Clausen and W. Dansgaard, Greenland ice sheet evidence of post-glacial volcanism and its climatic impact, Nature, 288, 230-235, 1980.

Herron, M.M., Impurity sources of $\mathrm{F}^{-}, \mathrm{C1}^{-}, \mathrm{NO}_{3}{ }^{-}$and $\mathrm{SO}_{4}{ }^{2-}$ in Greenland and Antarctic precipitation, Jour. Geophys. Res., 87, 3052-3060, 1982.

Ikegami, K., J. Inoue, K. Higuchi and A. Ono, Preliminary report on the vertical distribution of aerosol particles over the Nepal Himalayas, Seppyo, 42, 86-89, 1980.

Jickells, T., A. Knap., T. Church, J. Galloway and J. Miller, Acid rain on Bermuda, Nature 297, 55-57, 1982.

Johnson, B.B. and J.M. Chamberlain, Sodium, magnesium, potassium and calcium concentration in ice cores from the Law Dome, Antarctica, Geochim. Cosmochim. Acta, 45771 $776,1981$.

Kyle, P., J. Palais and R. Delmas, The volcanic record of Antarctic ice cores: Preliminary results and potential for future investigations, Annals Glaciol., 3, 172-177, 1982.

Lipschultz, F., O.C. Zafiriou, S.C. Wofsy, M.B. McElroy, F.W. Valois and S.W. Watson, Production of $\mathrm{NO}$ and $\mathrm{N}_{2} \mathrm{O}$ by soil nutrifying bacteria, Nature, 294, 641-643, 1981.

Lawson, D.R. and J.W. Winchester, Sulfur, potassium and phosphorus associations in aerosols from Southern American tropical rain forests, Jour. Geophys. Res., 84, 3723$3727,1979$.

Likens, G.E., F.H. Bormann, R.S. Pierce, J.S. Eaton and N.M. Johnson, Biogeochemistry of a Forested Ecosystem, Springer-Verlag, New York, 146 pp., 1977.

Mayewski, P.A., W.B. Lyons and N. Ahmad, Chemical composition of a high altitude fresh snowfall in the Ladakh Himalayas, Geophys. Res. Lettr., 10 (1), 105-108, 1983.

Mayewski, P.A., W.B. Lyons, G. Smith and M. Pourchet, Interpretation of the chemical and physical time-series retrieved from Sentik Glacier, Ladakh Himalayas, Jour. of Glaciol., in press.

Neftel, A., H. Oeschger, J. Schwander, B. Stauffer and R. Zumbrunn, Ice core sample measurements give atmospheric $\mathrm{CO}_{2}$ content during the past 40,000 yr., Nature, 295, 220-223, 1982.

$\mathrm{Ng}$, A. and C. Patterson, Natural concentrations of lead in ancient Arctic and Antarctic ice, Geochim. Cosmochim. Acta, 45, 2109-2121, 1981. 
Parker, B.C., E.J. Zeller and A.J. Gow, Nitrate fluctuations in Antarctic snow and firn: Potential sources and mechanisms of formation, Annals Glaciol., 3, 243-248, 1982.

Rampino, M.R. and S. Self, Historic eruptions of Tambora (1815), Krakatau (1883), and Agung (1963), their stratospheric aerosols and climatic impact, Quat. Res., 18, 127 . 143,1982

Risbo, T., H.B. Clausen and K.L. Rasmussen, Supernovae and nitrate in the Greenland Ice Sheet, Nature, 294, 637639. 1981.

Spicer, C.W., Nitrogen oxide reactions in the urban plume of Boston, Science, 215, 1095-1097, 1982.

Stallard R.F. and J.M. Edmond, Geochemistry of the Amazon 1. Precipitation chemistry and the marine contribution to the dissolved load at the time of peak discharge, Jour. Geophys. Res., 86, 9844-9858, 1981.
Thompson, L.G. and E. Mosley-Thompson, Microparticle concentration variation linked with climate: evidence from polar ice cores, Science, 212, 812-814, 1981.

Turman, B.N., Lightning detection from space, Am. Scientist, 67, 321-329, 1979 .

Yaalon, D.H., The concentration of ammonia and nitrate in rain water over Israel in relation to environmental factors, Tellus, 16, 200-204, 1964

Zeller, E.J. and B.C. Parker, Nitrate ion in Antarctic firn as a marker for solar activity, Geophys. Res. Lettr., 8, 895-898, 1981.
(Received February 7, 1983; accepted Apri1 29, 1983.) 